\title{
Rikki-Tikki-Tavi for aortic regurgitation
}

\author{
Kevin L. Greason, MD
}

From the Department of Cardiac Surgery, Mayo Clinic, Rochester, Minn.

Disclosures: Author has nothing to disclose with regard to commercial support.

Received for publication March 23, 2017; accepted for publication March 24, 2017; available ahead of print April $21,2017$.

Address for reprints: Kevin L. Greason, MD, Department of Cardiac Surgery, 200 First St SW, Rochester, MN 55902 (E-mail: greason.kevin@mayo.edu).

J Thorac Cardiovasc Surg 2017;154:56-7

$0022-5223 / \$ 36.00$

Copyright (c 2017 by The American Association for Thoracic Surgery

http://dx.doi.org/10.1016/j.jtcvs.2017.03.113

Readers of this issue of the Journal will find interest in this article from Luo and colleagues ${ }^{1}$ about transapical transcatheter aortic valve insertion with a new secondgeneration transcatheter valve insertion system, the J- Valve system (JC Medical, Inc). Luo and colleagues ${ }^{1}$ present standard outcome measures that are of interest (and somewhat concerning), but it is the use of the valve in the setting of aortic valve regurgitation that is most intriguing to me.

In this study, 21 patients underwent transapical transcatheter aortic valve insertion with the J-Valve system. Procedural success was obtained in $91 \%$ of patients and was defined according to Valve Academic Research Consortium 2 (VARC-2) criteria, which included absence of procedural mortality, correct positioning of a single prosthetic heart valve, and intended performance of the prosthetic heart valve (eg, mean aortic valve gradient $<20 \mathrm{~mm} \mathrm{Hg}$ ). ${ }^{1}$ Similar procedural success rates have been reported for other second-generation valves, such as the Engager (Medtronic, Minneapolis, Minn) valve (94\%) and the JenaValve (JenaValve Technology Inc, Irvine, Calif) valve (90\%).,3

The combined clinical efficacy of the J-Valve after 12 months was $76 \%$, which is again similar to that reported for the JenaValve $(81 \%))^{4}$ In the study of Luo and colleagues, ${ }^{1}$ reduced efficacy was mostly driven by findings from 5 patients who had mean aortic valve gradients of more than $20 \mathrm{~mm} \mathrm{Hg}$, which is concerning. It should also be noted that the median aortic valve gradient across the J-Valve increased during follow-up, from $12 \mathrm{~mm} \mathrm{Hg}$ postoperatively to $15 \mathrm{~mm} \mathrm{Hg}$ at 6 months and finally to $17 \mathrm{~mm} \mathrm{Hg}$ at 12 months. Such an increase has not been reported with the JenaValve, for which the mean aortic valve gradient remained relatively stable from postoperative to 12 months of follow-up (14.1-14.8 $\mathrm{mm} \mathrm{Hg}){ }^{4}$

My main interest in this study relates to the 4 patients with pure or dominant aortic valve regurgitation who underwent J-Valve insertion. In this group of patients, procedural success was $100 \%$ (no valve-in-valve insertions for residual aortic regurgitation), and echocardiography at 12 months of follow-up demonstrated no valvular or paravalvular regurgitation. These outcomes are excellent and should be compared with those reported by Roy and colleagues ${ }^{5}$ in

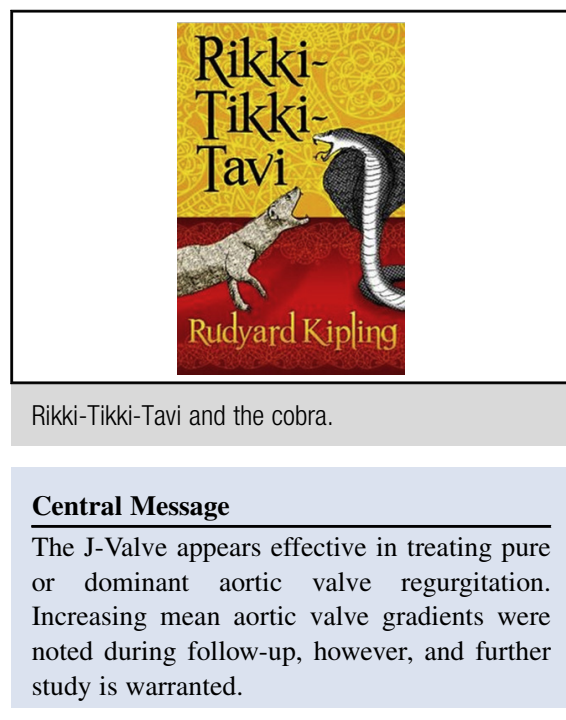

See Article page 46.

41 patients who received the CoreValve (Medtronic) for native aortic valve regurgitation. In the CoreValve study, procedural success was only $74 \%$, with $19 \%$ of the patients receiving valve-in-valve insertion for residual aortic regurgitation.

Why do I associate the J-Valve with Rikki-Tikki-Tavi, a short story by Rudyard Kipling (from The Jungle Book)? Rikki-Tikki is a valiant mongoose (the transcatheter valve) who fights Nag the cobra (aortic stenosis) in the classic mongoose-cobra battle (valve insertion for aortic valve stenosis). It is the unconventional fight, however, between Rikki-Tikki and Nagaina in the cobra's den (valve insertion for aortic valve regurgitation) for which Rikki-Tikki's true greatness is celebrated, for "very few mongooses, however wise and old they may be, care to follow a cobra into its hole." 6 Notwithstanding the allegory, further study is warranted.

\section{References}

1. Luo X, Wang X, Li X, Wang X, Xu F, Liu M, et al. Transapical transcatheter aortic valve implantation using the J-Valve system: a one-year followup study. J Thorac Cardiovasc Surg. 2017;154:46-55.

2. Holzhey D, Linke A, Treede H, Baldus S, Bleiziffer S, Wagner A, et al. Intermediate follow-up results from the multicenter Engager European pivotal trial. Ann Thorac Surg. 2013;96:2095-100.

3. Treede H, Mohr FW, Baldus S, Rastan A, Ensminger S, Arnold M, et al. Transapical transcatheter aortic valve implantation using the JenaValve system: acute and 30-day results of the multicentre CE-mark study. Eur J Cardiothorac Surg. 2012;41:e131-8.

4. Silaschi M, Treede H, Rastan AJ, Baumbach H, Beyersdorf F, Kappert U, et al. The JUPITER registry: 1-year results of transapical aortic valve implantation using a second-generation transcatheter heart valve in patients with aortic stenosis. Eur J Cardiothorac Surg. 2016;50:874-81. 
5. Roy DA, Schaefer U, Guetta V, Hildick-Smith D, Möllmann H, Dumonteil N, et al. Transcatheter aortic valve implantation for pure severe native aortic valve regurgitation. J Am Coll Cardiol. 2013;61:1577-84.
6. Kipling R. Rikki-Tikki-Tavi. Available at: https://www.vma.is/static/files/ enska/Bokmenntir/Short\%20Stories/RikkiTikkiTavi_Kipling.pdf. Accessed March 22, 2017. 